\title{
Quebrando estigmas: uma alternativa ao proibicionismo das drogas por meio da redução de danos
}

\author{
Breaking with stigmas: an alternative to drug prohibition through \\ harm reduction
}

\author{
Rompiendo estigmas: una alternativa al prohibicionismo de las \\ drogas mediante la reducción de daños
}

\begin{abstract}
JAMAIS FOMOS ZUMBIS: CONTEXTO SOCIAL E CRAQUEIROS NA CIDADE DE SÃO PAULO. Alves YDD. Salvador: EDUFBA; 2017. 350 p. ISBN 978-85-232-1587-3.
\end{abstract}

doi: 10.1590/0102-311X00014019

O livro Jamais Fomos Zumbis: Contexto Social e Craqueiros na Cidade de São Paulo é fruto da tese de doutorado em Antropologia defendida por Ygor Diego Delgado Alves, na Universidade Federal da Bahia (UFBA), publicada em 2017 como parte da coleção Drogas: Clínica e Cultura, lançada pelo Centro de Estudos e Terapia do Abuso de Drogas (CETAD) da UFBA. A obra consiste em uma importante contribuição da Antropologia para a Saúde Coletiva, visto que considera o uso generalizado do crack com base em uma perspectiva das Ciências Humanas, fornecendo um contraponto ao modelo proibicionista para lidar com a situação. Nesse sentido, entre a medicalização e a criminalização 1 imputadas aos usuários de drogas ilícitas, quando as únicas soluções para a questão seriam a sua abstinência e privação da liberdade, seja em clínicas de tratamento ou nos presídios, o autor do livro expõe outros meios para se lidar com a questão que valorizam, antes de tudo, a "autorregulação" 2 do uso pelos próprios usuários por meio da promoção da cidadania e dignidade humanas proporcionadas pela abordagem conhecida por Redução de Danos. Como alternativa às medidas repressivas que buscam retirar os usuários do convívio social, este tipo de abordagem pode gerar uma intervenção direta na estrutura de vida dos usuários sem tirar-lhes suas liberdades individuais.

É o caso de duas políticas públicas empreendidas pela Prefeitura de São Paulo a partir de 2013 e que são louvadas pelo autor do livro: o Programa De Braços Abertos (DBA) e os Campeonatos de Futebol que ocorrem entre os usuários de crack. O enorme potencial dessas iniciativas passa pelo impacto positivo gerado no cotidiano dos usuários quando adota medidas propositivas de acolhimento e cuidado, de modo a transformar o contexto social no qual eles estão inseridos, constituindo um contraponto à guerra às drogas que propaga o pânico moral por meio, principalmente, dos meios de comunicação, que atribuem aos usuários as conotações extremamente pejorativas de "dependentes químicos", pessoas que perderam a sua autonomia para se tornarem "escravas da droga" e condicionadas invariavelmente à criminalidade para "sustentar o seu vício”.

Todas essas conotações atribuídas pelo senso comum aos usuários de drogas condizem com a falta de conhecimento de sua realidade, ou seja, o seu "contexto social": a ordem do dia para compreender antropologicamente a questão. Inspirado pelos autores clássicos Jean-Paul Grund 2, Howard Becker 3 e Norman Zinberg 4, Ygor Alves busca em sua obra desmistificar a imagem dos usuários de crack concebidos como 
"zumbis", "mortos-vivos" que sobrevivem nos interstícios entre a vigília e o sono. Ainda que a incidência desse estigma possa ser percebida sobre uma parcela dos usuários, ou sobre uma parte de sua vida, ela é generalizada sobre o todo, como expõe o autor do livro quando traz ao leitor uma rica descrição do contexto no qual esses usuários estão inseridos ao revelar como eles produzem sua própria cultura, mesmo que seja uma "cultura desviante" 3 , mas ainda assim dotada de toda uma sociabilidade que é gerada em torno das práticas de uso da substância que, inclusive, desenha mecanismos próprios de "controles sociais informais" 4 da droga independentes dos "controles formais" 4, na maioria das vezes repressivos, administrados pelo Estado. A própria elaboração do DBA demonstra essa desmistificação, uma vez que o Programa foi construído em diálogo e participação ativa entre os usuários e a Prefeitura de São Paulo, que buscou justamente adentrar na sua realidade sem os pré-julgamentos aos quais são acometidos.

Como bom antropólogo, na busca em conhecer o contexto social dos usuários de crack, Ygor Alves adotou o método de pesquisa consagrado de sua disciplina: a etnografia. Assim, o autor conviveu intensamente com seus interlocutores, abandonando os pré-conceitos culturais próprios a um estrangeiro para só assim conseguir compreender os seus pontos de vista sobre o mundo em que vivem. Quando se trata de atividades ilícitas, a pesquisa etnográfica se depara com questões éticas que colocam em risco a sua continuidade devido à própria natureza de seu objeto. Convivendo em territórios onde se comercializa e se consome substâncias ilícitas, com pessoas muitas vezes envolvidas com a criminalidade, a imersão do pesquisador na cultura que pretende estudar fica bastante delicada, visto sob constante suspeita, alvo de olhares desconfiados, sendo recorrentemente indagado sobre a razão de se estar em uma "biqueira" - local onde se comercializa drogas - observando as pessoas, como um jornalista ou um policial disfarçado. A constante negociação do pesquisador para a sua bem-sucedida inserção em campo não estava livre, assim, de recorrentes ameaças à sua própria vida, havendo um trabalho redobrado para conquistar a confiança de seus interlocutores, empreendimento realizado com maestria quando afirma ter buscado sempre a transparência de sua condição de pesquisador no local.

Para bem se compreender o fenômeno do uso de drogas ilícitas é injusto enfatizar os efeitos farmacológicos da substância sobre o organismo, tampouco as condições psicológicas do usuário, e menos ainda o contexto social no qual os usuários estão inseridos. É necessário, então, que se considere a tríade substância-indivíduo-sociedade em seu conjunto; contudo, não é o que acontece quando o domínio do social é relegado à margem dos estudos sobre o uso de drogas, inviabilizando que se tenha uma visão mais coerente dos fatos que não seja condicionada pelos estigmas que atribuem à simples experimentação da droga o risco iminente para que o usuário seja levado a um "uso compulsivo" 4, como se não fosse possível um "uso controlado" 4 da substância.

Assim, é imprescindível que o usuário "saiba usar a droga para não ser usado por ela”, jargão relembrado pelo autor para se referir aos controles sociais desenvolvidos pelos próprios usuários, com todos os valores e regras de conduta aí envolvidos que só podem ser percebidos mediante o trabalho de campo. Nesse sentido, as cenas de uso descritas trazem ao leitor informações reveladoras sobre a autorregulação do uso do crack no sentido de se obter a melhor experiência possível com a droga, evitando-se a "paranoia", de modo a favorecer a "sintonia" entre as pessoas do grupo. A própria construção social do "noia" - aquele usuário compulsivo de comportamento agressivo que justifica a privação de sua liberdade - é gerada não como consequência somente dos efeitos da droga sobre o organismo, mas como internalização de crenças que partem da sociedade abrangente sobre o grupo desviante. Os próprios usuários acreditam no que está sendo dito sobre eles e assumem estas concepções para si, o que reverbera no próprio contexto de uso da droga, cujas fronteiras entre um uso abusivo e 
controlado passam invariavelmente pela própria estrutura de vida dos usuários. Do mesmo modo, o contexto proibicionista afeta diretamente a relação do usuário com a droga, podendo favorecer uma possível "paranoia" e posturas antissociais que complexificam a autorregulação para um uso não problemático da substância. Apesar disso, muitos usuários bem sabem quando poderão minimizar os danos gerados pelo uso da droga.

É considerando, portanto, a autonomia dos usuários que as políticas públicas de Redução de Danos ganham espaço na sociedade, a contraponto dos modelos proibicionistas da guerra às drogas. Nesse sentido, Ygor Alves se aproxima da militância, em suas fronteiras com o saber acadêmico, quando produz uma obra de excelente qualidade capaz de fortalecer as lutas antiproibicionistas que prezam, antes de tudo, pela crescente humanização dos usuários de drogas subsumidos, ainda hoje, ao controle das políticas de segurança pública e higienização do espaço urbano, preocupadas em somente reproduzir o status quo que garante cada vez mais lucros à indústria da guerra, bem como a manutenção da segregação social/racial. Como ressalta Ygor Alves, é mais do que necessário, para que haja justiça social, que as medidas proibicionistas de gentrificação saiam de moda para dar lugar de uma vez por todas às medidas integrativas levadas a cabo pela Redução de Danos.

\section{Francisco Savoi de Araujo 1}

1 Universidade Federal da Bahia, Salvador, Brasil. fransavoi@yahoo.com.br

\section{Informação adicional}

ORCID: Francisco Savoi de Araujo (0000-00029129-6585).

1. Vargas EV. Os corpos intensivos: sobre o estatuto social do consumo de drogas legais e ilegais. In: Duarte LFD, Leal OF, organziadores. Doença, sofrimento, perturbação: perspectivas etnográficas. Rio de Janeiro: Editora Fiocruz; 1998. p. 121-36.

2. Grund JPC. Drug use as a social ritual - functionality, symbolism and determinants of self regulation. Rotterdam: Institut voor Verslavingsonderzoek; 1993.

3. Becker HS. Outsiders. Estudos de sociologia do desvio. Rio de Janeiro: Zahar; 2008.

4. Zinberg N. Drug, set and setting. New Haven: Yale University Press; 1984. 